\title{
A COMPARATIVE ANALYSIS OF THE PROFESSIONAL COMPETENCE LEVEL OF FUTURE TEACHERS OF FINE ART OF THE ZAPORIZHZHIA REGION IN THE CONDITIONS OF THE CONCEPT OF A NEW UKRAINIAN SCHOOL
}

\author{
Svitlana Davydova \\ Department of Pedagogy and Pedagogical Skills \\ Melitopol State Bogdan Khmelnitsky Pedagogical University \\ 20 Getmanska str., Melitopol, Ukraine, 72300 \\ davydovasv007@gmail.com
}

\begin{abstract}
The article is devoted to the study of the problem of training future teachers of fine art in the context of the implementation of the Concept of the New Ukrainian School in order to comparatively analyze the existing level of their professional training in accordance with the new requirements and needs of society, where project technology is the basis of training as a condition for the development of a successful person.

The author identifies issues related to the training of teachers of fine art in higher education institutions that require scientific research in order to update the process of preparing future teachers of fine art to work in the New Ukrainian School, clarifies the essence of the concept of professional competence of a teacher of fine art, its structure and criteria for assessing the levels of formation given competency. In the process of research, the advantages of teaching with the help of creative design, its capabilities in the training of fine art teachers are revealed and substantiated.

During the ascertaining experiment, which was conducted with the participation of students of the Municipal institution of higher education "Khortytsia National Training and Rehabilitation Academy" of the Zaporizhzhia Regional Council, it was established and justified the need to update the process of professional training of teachers of fine art and the possibility of increasing the existing level of professional competence formation using creative design as an effective means of formation. The relationship between the level of formation of professional competence and the motivational sphere has been practically established, the need to use the visual art of creative design in the training of teachers is logically substantiated.
\end{abstract}

Keywords: professional competence, teacher of fine arts, design activities, creative design activities.

DOI: $10.21303 / 2504-5571.2019 .001078$

\section{Introduction}

Modern Ukrainian education is in a state of global reform, relating to all its levels; this influenced the requirements for the professional competence of teachers of fine art, their personal qualities and the actual process of training in higher education institutions. Such changes were preceded by a number of scientific studies on the training of specialists, teachers of fine art with the involvement of advanced European and world experience in the field of pedagogy, took the form of the following updates: Law of Ukraine "On Education" [1], Law of Ukraine "On Higher Education" [2], National Doctrine of Education Development [3] Concept of the New Ukrainian School [4] Concept of the development of teacher education [5], practical implementation (experiment - implementation of the Concept of the New Ukrainian School 2017-2023) have demonstrated positive results and continues. So, the modernization of Ukrainian education has led to significant changes in its concept and development guidelines, the integration of the European experience of science and education in domestic practice, taking into account the requirements of the rapidly changing labor market for the professional qualities of a world-class specialist.

Thus, Ukrainian education has received a powerful impetus in its development and has positive results today, however, not all branches and specialties of education have been studied and updated at the necessary theoretical, methodological and practical levels. This situation is observed in the training of teachers of fine art, because the modernization of Ukrainian education takes place at all its levels and requires a certain time; the primary task was the research and development of 
teaching materials for primary education, which was necessary for the implementation of the New Ukrainian School and the training of relevant personnel. The second stage was the methodological and personnel support of the basic secondary education of the New School, prompting scientists to research the actual process of training teachers of fine art to form their professional competence in accordance with the needs and requirements of the educational process and society, where there is a need for an in-depth study of design technologies, their adaptation for a specific subject, because the project method is the basis of the New Ukrainian School. Under these conditions, there is a need to study the professional training of teachers of fine art with the aim of updating the process of their training in higher education institutions.

\section{Directions goal Strategy:}

- identify aspects that require updating and refinement in the training of teachers of fine art;

- specify the essence of professional competence of the teacher of fine art of the New Ukrainian School and determine the structure of competencies;

- conduct a stating experiment among future teachers of fine art of the Zaporizhzhia region in order to determine the level of professional competence formation (according to modern requirements) and its relationship with the motivational sphere;

- provide practical justification for the need for an in-depth study of the project method and the involvement of creative design before the training of future art teachers in order to effectively shape their professional competence at the modern level.

The aim of research is justification of the feasibility of an in-depth study of the project method in the training of future teachers of the visual arts of the New Ukrainian School, where creative design acts as a means of formation.

\section{Materials and methods}

The research methodology consists in using a set of methods that provide a systematic study of the indicated problem, namely:

- theoretical - a theoretical and critical analysis of the problem of training future teachers of fine art, systematization, generalization of the information received (the nature and structure of the professional competence of the teacher of fine art of the New Ukrainian School);

- empirical - methods of mass collection of empirical material (testing, questioning, interviews), with the help of which the level of professional competence and the level of project knowledge of future teachers of fine art were studied;

- pedagogical experiment (ascertaining) statistical methods for processing experimental data (the need to update the process of preparing teachers of fine art with the use of in-depth study of the project method and creative design as an effective means of building the professional competence of teachers of fine art of the New Ukrainian School was checked and substantiated).

\section{Result}

In the 21st century, the development of civilization is characterized by rapid technological progress, a high level of cross-border migration and a new labor market structure. Changing the consciousness and needs of society sets a different vector of priorities, which leads to significant changes in the competencies of specialists. Thus, in the structure of higher education, the main emphasis is on the formation of universal competencies and the need to study the project method is emphasized. Teachers of the new formation should become agents of change and part of the New Ukrainian School. A modern teacher is a coach, facilitator, tutor and effective moderator of the individual educational trajectory of the child, where its activities are directly related to the latest forms and methods of teaching with an emphasis on creative thinking [6, p. 36]. The art teacher is responsible not only for its subject, but for a much larger segment in the training of students - the integration of a creative approach to each school subject. Under these circumstances, art education, aesthetic education, the development and formation of creative thinking among students is a prerequisite for the effective interaction of students with teachers during the educational process, provided by the New Ukrainian School. So, the importance of the professional activities of teachers of fine art is growing, because only they can fully ensure the disclosure of 
creative potential and the formation of the necessary competencies of students to create a harmonious educational process.

Ukrainian scientists identified a number of problematic aspects of the training of teachers of fine art with the identification of issues requiring improvements and modernization: updating the methodological base [7, p. 12]; integration of world experience, modern ideas and innovations in the training of teachers of fine art [8, p. 11]; additions of forms, methods, training technologies in accordance with international standards [9, p. 60]; increasing the level of students' academic independence [10, p. 78-79]; changing the vector of training - practical and orientation training based on a harmonious combination of theoretical knowledge with the skills of their practical implementation [11]; in-depth study of the project method and the possibilities of creative project-based learning [12].

Thus, after identifying the problematic aspects of preparing a teacher of fine art and issues requiring improvements, let's consider it necessary to clarify the essence of the professional competence of teachers of fine art, is a combination of knowledge, skills, experience in art and pedagogy, a special way of thinking, views, value orientations, individual personality traits that determine the ability for dynamic and combined use in professional activities; skills for successful socialization and the implementation of professional activities (student training), which involves attracting the latest pedagogical developments, design technologies and the ability to learn throughout life.

To date, there are no unified approaches to the structure of professional competence of a teacher of fine art, but the distribution trend, subordinated to the normative documents regulating the educational process, is a universal teacher's competence and subject competencies.

Such a separation of the structure of professional competence of the teacher of fine arts provided an opportunity to formulate two blocks of competencies: general pedagogical and special artistic. Let's consider in more detail the blocks and their components.

General pedagogical block: methodological, communicative, social, psychological and pedagogical, prognostic, reflective, digital, managerial, project competence.

Special artistic block: general cultural, multi-artistic, cognitive-technological, graphic, artistic-aesthetic, creatively creative, coloristic competencies [13, p. 259-260].

Particular attention should be paid to project competence, since the value of project training is that it can vary your own educational path in accordance with individual tastes and capabilities [14, p. 94], it contains elements of interactive learning, where all participants in the educational process actively interact with each other, exchanging information, jointly solving educational problems, modeling situations, evaluating their actions, plunging into the atmosphere of business cooperation to solve a number of problems in accordance with their interests, educational and personal needs. Such training is characterized by a constant change in the types of educational activities [15, p. 269].

To establish the level of professional competence formation of future art teachers, criteria (high, sufficient, low) and their indicators, modified methods for diagnosing the level of formation of professional competence of future art teachers in accordance with certain competencies were determined (Table 1).

Table 1

Criteria and indicators of the formation of professional competence of teachers of art

\begin{tabular}{ll}
\hline \multicolumn{1}{c}{ Criteria } & \multicolumn{1}{c}{ Indicators } \\
\hline K1 - Motivational & $\mathrm{a}-$ motive for choosing the HEU \\
& $\mathrm{b}-$ motive for choosing a future profession \\
& $\mathrm{c}-$ educational motivation \\
& $\mathrm{a}-$ general pedagogical skills \\
K2 - Operational-activity & $\mathrm{b}-$ possession of art skills \\
& $\mathrm{a}$ - assessment of the types of pedagogical activity
\end{tabular}


The next step was a conducting experiment with the involvement of students from the municipal institution of higher education "Khortytsia National Training and Rehabilitation Academy" of the Zaporizhzhia Regional Council, which trains future art teachers in the Zaporizhzhia region. Studies were conducted during 2018-2019, covering three groups of senior students: two fourth and third courses. The total number of students was 50 people. Students were tested by certain methods to diagnose the level of professional competence formation (each competency) of future art teachers, the data obtained made it possible to compare the existing level of formation in accordance with modern requirements. The results can be studied with respect to each competency and the general level of professional competence. Particular attention was paid to indicators of the formation of project competence, motivation and their relationship with the formation of professional competence. Motivation was considered in three hierarchical planes: the motivation for learning in a higher education institution, the main motives for choosing a profession, and educational motivation (Table 2). The data obtained were divided into three levels (high, sufficient, low) and were considered as a percentage, where 50 people are equal to $100 \%$ (Table 3 ).

The calculations were carried out according to the formula of the arithmetic mean data of each indicator in percent according to the following formula: the calculation of the arithmetic mean of several numbers is the number, the sum of the digits (indicator data) is divided by their number

$$
\frac{a_{1}+\cdots+a_{n}}{n}
$$

where $a_{1}+\cdots+a_{n}$ is the percent is the indicator data, $\mathrm{n}$ is the number of students. Data rounding was carried out to integers, taking into account objective factors.

Table 2

Comparative analysis of the formation levels of the motivational sphere of future art teachers

\begin{tabular}{|c|c|c|c|c|c|c|}
\hline Student learning motivation & \multicolumn{2}{|c|}{ high } & \multicolumn{2}{|c|}{ sufficient } & \multicolumn{2}{|c|}{ low } \\
\hline Motivation for teaching in a higher education institution & & $26 \%$ & & $44 \%$ & & $30 \%$ \\
\hline The main motives for choosing a profession & $24 \%$ & $24 \%$ & $48 \%$ & $46 \%$ & $28 \%$ & $30 \%$ \\
\hline Learning motivation & & $22 \%$ & & $52 \%$ & & $26 \%$ \\
\hline
\end{tabular}

Table 3

Comparative analysis of the professional competence levels of future teachers of art

\begin{tabular}{|c|c|c|c|c|c|c|}
\hline \multirow{2}{*}{$\begin{array}{l}\text { Professional competence of future art teacher } \\
\text { Competencies }\end{array}$} & \multicolumn{2}{|c|}{ high } & \multicolumn{2}{|c|}{ sufficient } & \multicolumn{2}{|c|}{ low } \\
\hline & & & & & & \\
\hline \multicolumn{7}{|l|}{ General pedagogical block } \\
\hline Methodical & \multirow{8}{*}{$10 \%$} & $10 \%$ & \multirow{8}{*}{$44 \%$} & $48 \%$ & \multirow{8}{*}{$46 \%$} & $42 \%$ \\
\hline Communicative & & $8 \%$ & & $40 \%$ & & $52 \%$ \\
\hline Social & & $18 \%$ & & $48 \%$ & & $34 \%$ \\
\hline Psychological and pedagogical & & $12 \%$ & & $42 \%$ & & $46 \%$ \\
\hline Prognostic & & $14 \%$ & & $46 \%$ & & $40 \%$ \\
\hline Managerial & & $6 \%$ & & $44 \%$ & & $50 \%$ \\
\hline Digital & & $8 \%$ & & $50 \%$ & & $42 \%$ \\
\hline Design & & $6 \%$ & & $36 \%$ & & $58 \%$ \\
\hline Arithmetic mean of two blocks & $12 \%$ & & $46 \%$ & & $42 \%$ & \\
\hline \multicolumn{7}{|l|}{ Specially art block } \\
\hline General cultural & \multirow{7}{*}{$14 \%$} & $12 \%$ & \multirow{7}{*}{$46 \%$} & $44 \%$ & \multirow{7}{*}{$40 \%$} & $44 \%$ \\
\hline Polyartistic & & $14 \%$ & & $46 \%$ & & $40 \%$ \\
\hline Cognitively technological & & $16 \%$ & & $42 \%$ & & $42 \%$ \\
\hline Fine & & $12 \%$ & & $50 \%$ & & $38 \%$ \\
\hline Artistic and aesthetic & & $14 \%$ & & $48 \%$ & & $38 \%$ \\
\hline Coloristic & & $16 \%$ & & $48 \%$ & & $36 \%$ \\
\hline Creative & & $16 \%$ & & $44 \%$ & & $40 \%$ \\
\hline
\end{tabular}


Thus, the obtained results indicate that the existing level of professional competence formation requires further development, due to the requirements of the New Ukrainian School (Fig. 1).

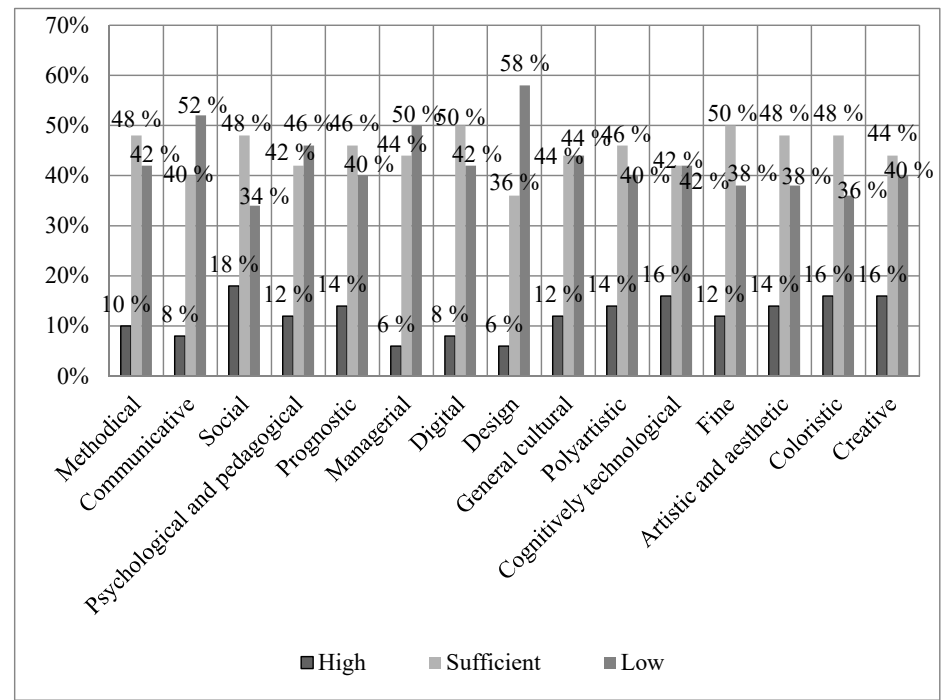

Fig. 1. The results of the formation of professional competence of future teachers of fine art of the Zaporizhzhia region

The diagram shows the optimal percentage of a sufficient level of the professional competence formation of a teacher of fine arts (total $46 \%$ ), but the percentage of high and low levels has deviations from the norm: high (total $12 \%$ ), low (overall $42 \%$ ). So, the low level is $42 \%$, and the average is $46 \%$, which indicates the need to update the process of training teachers of fine arts in higher education institutions with the aim of relevant additions to their educational process.

The next step in our study is studying the data on the professional competence level of future teachers of fine art in accordance with the data of the students' motivational sphere (motivational aspect) and their relationship (Fig. 2).

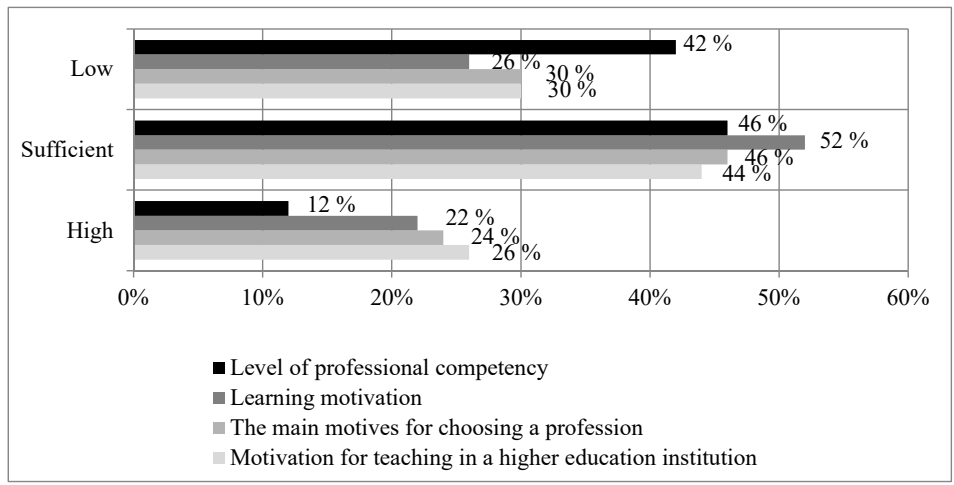

Fig. 2. A comparative analysis of the levels of professional competence formation with student motivation

The results clearly demonstrate the relationship between the motivational sphere and the formation of professional competence: a high ratio of $24 \%$ (general) to $12 \%$, a sufficient ratio of $48 \%$ (average) to $46 \%$, a low ratio of $28 \%$ (average) to $42 \%$, this proves the direct influence of motivation on the level of formation of professional competence of future art teachers. It should be noted that creative project activities create positive motivation of students during training and project implementation.

Considering separately the data on the formation of project competence, insufficient in accordance with the requirements of the New Ukrainian School (high $6 \%$, sufficient $36 \%$, low 
$58 \%$ ), where project training is the basis, we will analyze the scientifically substantiated advantages of project training.

Based on scientific research, let's summarize that creative design activities in the educational process:

- teaches to freely and independently navigate the scientific, methodological and reference literature and acquire the necessary knowledge;

- is a means of developing basic types of thinking;

- promotes harmonious psychological development; the like;

- preserves and enhances the independence of students, the desire to create, create and

- work with "amenable material" strengthens the emotional-volitional sphere of students;

- serves as a means of active development of intellectual abilities, teaches to think from the general - abstract to the concrete;

- promotes awareness of the importance of the chosen profession;

- motivates to learning and gaining professional experience;

- attracts trainees to objective self-education;

- promotes interiorization (transition from external influences to the internal plan) and exteriorization (transition of internal actions to external), that is, their transformation with obtaining a material result and practical (partially new) knowledge and experience;

- promotes self-awareness as the creator of one's own activity, study, life, and the like;

- is a factor of positive motivation - the project gets and is implemented in accordance with their own interests, needs and opportunities;

- provides the formation of creative systemic thinking of students;

- accustoms to a systematic, staged activity, subordinated to a specific goal (such activity is a transformative element - information, energy, oneself, a transition to a new level of consciousness, learning);

- is one of the elements in the formation of a culture of business communication, provides skills to reasonably and reasonably defend their positions;

- is a means of stimulating the imagination to generate new ideas (quantity), search for atypical, alternative solutions, their analysis and synthesis as the basis of innovative thinking;

- teaches to design an internal plan of action for its external practical implementation [16-20].

Thus, the involvement of creative design and its capabilities will allow updating the training of fine art teachers at the required level in accordance with the requirements of the New Ukrainian School.

Thus, the use of creative design in the professional training of teachers of fine art will qualitatively increase the level of professional competence formation of future teachers of fine art of the New Ukrainian School (Fig. 3).

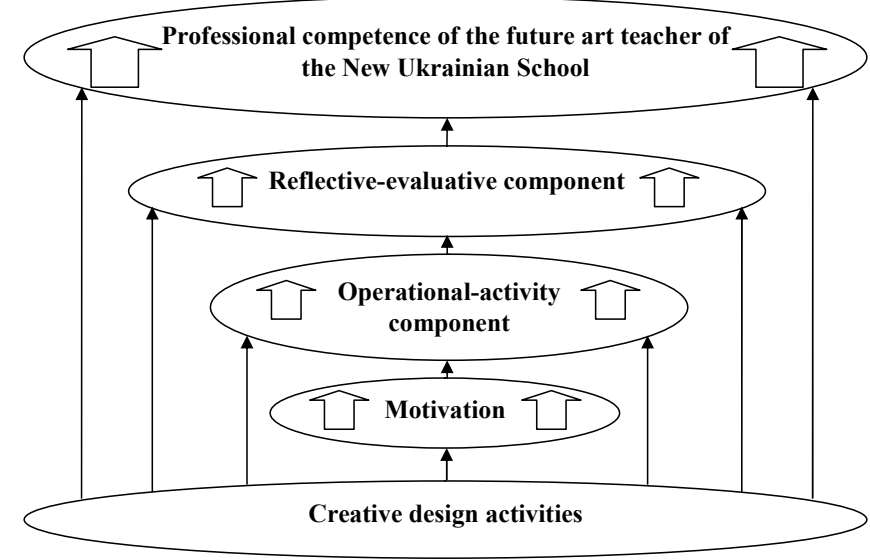

Fig. 3. Scheme on the emergence of creative design for the professional competence formation of future teachers of fine art 


\section{Discussion}

The results of our research indicate the need for updating the process of professional training of teachers of fine art, where creative design is the means of formation.

The studies are based on the requirements of modern education in Ukraine and the analysis of data on the training of specialists in various industries (designers, clothing designers, technology and labor teachers, geography, etc.) in recent years, where project training gave effective results in the formation of their professional competence. It is impossible to conduct a comparative analysis on the application of the project method or creative design in the formation of the professional competence of teachers of art, because this topic was not the subject of a separate study in national science. Thus, based on the obtained data, it is only possible to state the existing level of professional competence of teachers of fine art in accordance with the requirements of the New Ukrainian School, which demonstrates the need to modernize their professional training and indicates a low level of project knowledge and motivation for students to study and compare with foreign experience in the use of design technologies in teacher training.

During our study, we relied on the results obtained and were guided by the experience of foreign experts (American and European), already explored the project method as a means of training and the formation of professional competence of students from creative specialties and noted its advantages:

- students are becoming more interested in a particular subject or in the entire learning process, increasing their academic independence [21];

- there is an increase in academic performance, students involved in the project take more academic responsibility for their own education than in the classical model of instruction [22];

- develops complex thinking skills and the ability to solve problems of a higher order, learn to cooperate and communicate in a specific team [23];

- provides great opportunities for learning - multi-variant training with different pedagogical tools $[24,25]$.

We also analyzed and compared existing teaching methods using the project method and educational experiments where project technologies were used, demonstrated their effectiveness and efficiency in foreign practice: the use of projects in teaching students in Greece (Rhodes) [26], project training as a dynamic approach to teaching, in which students study real problems, while developing the skills of the 21st century, working in small joint groups - the experience of American scientists (New York) $[27,28]$, the project method in $\mathrm{n}$ teaching and teaching from the experience of scientists of India (New Daily) [29].

The prospects for further research is the use of creative design in the training of teachers of fine arts of Zaporizhzhia and other regions of Ukraine in order to increase the level of formation of their professional competence, is the integration of foreign educational experience in domestic practice.

Our research has a narrow focus - it is the professional training of teachers of fine art, the formation of their professional competence, where creative design becomes a universal tool, with minimal interference in the existing process of teacher training can provide the necessary increase in the level of formation of their professional competence.

The results of a comparative analysis of the levels of professional competence formation of future art teachers allow to substantiate the need for a separate scientific study on the use of creative design in their professional training as a means of building professional competence, which will positively affect the general training of fine art teachers in higher education institutions and contribute to the implementation of the New Ukrainian Concept school.

\section{Conclusions}

Thus, during a stating experiment in the Zaporizhzhia region (Municipal institution of higher education "Khortytsia National Training and Rehabilitation Academy" of the Zaporizhzhia Regional Council), the need to update the process of training of future teachers of fine art in higher education institutions is established and substantiated in order to increase the level of education their professional competence in accordance with the realities of our time. During the experiment, the relationship 
between the motivational sphere and the level of formation of professional competence of future art teachers and the need to engage in creative design before their training is determined.

Thus, the study proves the appropriateness of the use of the creative arts of creative design in the training of teachers as a necessity of modernity and a necessary educational tool in the context of the implementation of the New Ukrainian School. The obtained data is part of the dissertation study "The Formation of Professional Competence of Future Visual Art Teachers Using Creative Design Activities", which aims to update the process of professional training of visual art teachers in accordance with modern requirements for the professional competence of world-class specialists and is valuable for the implementation of the Concept of the New Ukrainian School.

\section{References}

[1] Pro osvitu (2017). Zakon Ukrainy No. 2145-VIII. 05.09.2017. Available at: https://zakon.rada.gov.ua/laws/show/2145-19

[2] Pro vyshchu osvitu (2014). Zakon Ukrainy No. 1556-VII. 01.07.2014. Available at: https://zakon.rada.gov.ua/laws/show/1556-18

[3] Pro Natsionalnu doktrynu rozvytku osvity (2002). Ukaz Prezydenta Ukrainy Doktryna No. 347/2002. 17.04.2002. Available at: https://zakon.rada.gov.ua/laws/show/347/2002

[4] Nova ukrainska shkola (2016). Ministerstvo osvity i nauky Ukrainy. Available at: https://mon.gov.ua/storage/app/media/zagalna\%20serednya/nova-ukrainska-shkola-compressed.pdf

[5] Pro zatverdzhennia kontseptsii rozvytku pedahohichnoi osvity (2018). Nakaz Ministerstva osvity i nauky Ukrainy No. 776. 16.07.2018. Available at: https://mon.gov.ua/ua/npa/pro-zatverdzhennya-koncepciyi-rozvitku-pedagogichnoyi-osviti

[6] Osvita v Ukraini: bazovi indykatory. Informatsiino-statystychnyi biuleten rezultativ diialnosti haluzi osvity u 2017/2018. Available at: https://mon.gov.ua/storage/app/media/nova-ukrainska-shkola/1serpkonf-informatsiyniy-byuleten.pdf

[7] Bozhko, L. V. (2018). Formuvannia profesiinoi kompetentnosti maibutnikh uchyteliv tekhnolohii i kreslennia zasobamy proektuvannia. Kryvyi Rih, 263

[8] Vysikailo, T. V. (2017). Formuvannia fakhovoi kompetentnosti maibutnikh uchyteliv obrazotvorchoho mystetstva u protsesi plenernoi praktyky. Kharkiv, 243.

[9] Danyliuk, O. (2013). Formuvannia profesiinoi kompetentnosti maibutnoho uchytelia obrazotvorchoho mystetstva. Humanitarnyi visnyk Derzhavnoho vyshchoho navchalnoho zakladu Pereiaslav-Khmelnytskyi derzhavnyi pedahohichnyi universytet imeni H. S. Skovorody. Seriia: Pedahohika. Psykholohiia. Filosofiia. Pereiaslav-Khmelnytsk, 28 (2), 58-61.

[10] Krasovska, O. O. (2017). Teoretychni ta metodychni zasady profesiinoi pidhotovky maibutnikh uchyteliv pochatkovoi shkoly u haluzi mystetskoi osvity zasobamy innovatsiinykh tekhnolohii. Zhytomyr, 491.

[11] Piddubna, O. M. (2019). Predmetni kompetentnosti v pidhotovtsi vchytelia obrazotvorchoho mystetstva. Suchasni tendentsii rozvytku osvity i nauky v interdystsyplinarnomu konteksti. Dialoh kultur yak chynnyk intehratsii. Varshava - Uzhhorod Kherson: Posvit, 95-99.

[12] Stritievych, T. M. (2017). Rozvytok fakhovoi kompetentnosti u protsesi profesiinoi pidhotovky maibutnikh uchyteliv obrazotvorchoho mystetstva. Naukovi zapysky Kirovohradskoho derzhavnoho pedahohichnoho universytetu imeni Volodymyra Vynnychenka. Seriia: Pedahohichni nauky, 150, 107-110.

[13] Davydova, S. (2018). Analiz strukturnykh skladovykh profesiinoi kompetentnosti uchytelia obrazotvorchoho mystetstva. Melitopolskyi derzhavnyi pedahohichnyi universytet imeni Bohdana Khmelnytskoho, 1 (20), 256-262.

[14] Izbash, S. S. (2010). Realizatsiia tvorchykh proektiv u navchalnomu protsesi suchasnoi shkoly. Naukovyi visnyk Melitopolskoho derzhavnoho pedahohichnoho universytetu. Seriia: Pedahohika, 5, 92-97.

[15] Anosov, I. P., Izbash, S. S. (2014). Interaktivnyie metodyi obucheniya v prepodavanii distsiplinyi «Osnovyi pedagogicheskogo masterstva». Modernizatsiya sistemyi nepreryivnogo obrazovaniya, 267-275.

[16] Kurach, M. S. (2016). Teoretychni i metodychni zasady navchannia khudozhnoho proektuvannia maibutnikh uchyteliv tekhnolohii. Kyiv, 478.

[17] Voronenko, T. I. (2016). Klasyfikatsiia navchalnykh proektiv. Problemy suchasnoho pidruchnyka, 17, 79-91.

[18] Izbash, S. S. (2007). Proektna diialnist yak faktor sotsialno-profesiinoi navchannia. Kyiv, 20.

[19] Shevchenko, A. I. (2017). Metodyka navchannia khudozhnoho proektuvannia maibutnikh fakhivtsiv z dyzainu adaptatsii studentiv pedahohichnoho universytetu. Melitopol, 290.

[20] Bozhko, L. (2018). Formuvannia profesiinoi kompetentnosti maibutnikh uchyteliv tekhnolohii i kreslennia zasobamy proektuvannia. Kryvyi Rih, 263.

[21] Project-Based Learning (2019). Available at: https://www.edutopia.org/project-based-learning

[22] Boaler, J. (1999). Mathematics for the moment, or the millennium? Education Week. Available at: https://www.edweek.org/ew/ articles/1999/03/31/29boaler.h18.html 
[23] Overview and Benefits of Project-Based Learning. Available at: https://www.intel.com/content/dam/www/program/education/us/en/documents/project-design/projectdesign/benefits-of-projectbased-learning.pdf

[24] Przybysz-Zaremba, M., Kolodziejski, M. (2017). Project method in educational practice. University Review, 11 (4), $26-32$ Available at: https://www.researchgate.net/publication/321747866_Project_method_in_educational_practice

[25] Telegina, N., Drovosekov, S., Vasbieva, D., Zakharova, V. (2019). The Use of Project Activity in Teaching Mathematics. Eurasia Journal of Mathematics, Science and Technology Education, 15 (8). doi: http://doi.org/10.29333/ejmste/108439

[26] Maria, K. (2015). The Use of Project Method in Teaching Arts - An Interdisciplinary the Use of Project Method in Teaching Arts, An Interdisciplinary Approach in High School. Review of European Studies, 7 (11), 159-165. doi: http://doi.org/10.5539/ res.v $7 \mathrm{n} 11 \mathrm{p} 159$

[27] Stivers, J. (2010). Project-Based Learning. URL: http://www.fsmilitary.org/pdf/Project_Based_Learning.pdf

[28] Adom, D., Adam, S., Agyemang, O. (2016). Effective Instructional Methods and Strategies for Teaching Art History. International Journal of Art and Art History, 4 (2), 45-62. doi: http://doi.org/10.15640/ijaah.v4n2a4

[29] Syllabus of arts education (2008). National Council of Educational Research and Training Sri Aurobindo Marg. New Delhi, 222.

\title{
THE CONTENT AND STRUCTURE OF SOCIAL EDUCATION OF STUDENT YOUTH IN CHRISTIAN DENOMINATIONS OF THE PEOPLES OF THE NORTHERN AZOV REGION
}

\author{
Maryna Kuznietsova \\ B. Khmelnitsky Melitopol State Pedagogical University \\ 20 Hetmanska str., Melitopol, Ukraine, 72300 \\ Department of English language \\ V. N. Karazin Kharkiv National University \\ 4 Svobody Sq., Kharkiv, Ukraine, 61022 \\ marina.nikolaevna.gm@gmail.com
}

\begin{abstract}
The article analyzes the scientific research on the coverage of aspects and the content of social education of student youth in Christian denominations in the Northern Azov region.

The essence and structure of the peculiarities of the formation of social education of the student youth in the Christian confessions of the peoples of the North Azov region, in particular, in the global system of development of the inter-religious environment are determined.

It is considered in the article, that there is a great necessity to study the social environment, in which the social education of student youth is formed, and its interaction with various subjects of educational influence.

The basic concepts that make up the conceptual sphere are identified and the strategies of interaction between the state and religious organizations on the issues of social education of student youth are considered, which should be taken into account in the development of social programs, which should be extended to the social education of students as a whole and its individual aspects, as well as to find new opportunities to improve the social education of students.
\end{abstract}

Keywords: social education, student youth, Christian denominations, the peoples of the North Azov region, education.

DOI: $10.21303 / 2504-5679.2019 .001076$

\section{Introduction}

An analysis of recent research and publications shows that the vast majority of works lack a clear structure for the socialization of student youth in the Christian denominations of the Northern 